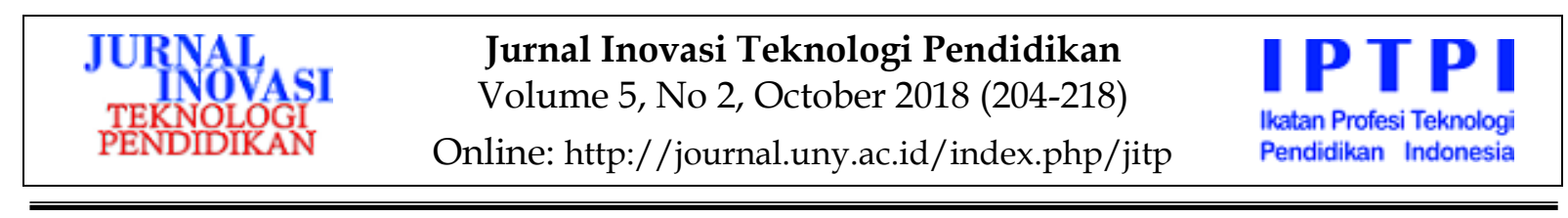

\title{
MULTIMEDIA PEMBELAJARAN BERBASIS WEB PADA MATA PELAJARAN AKUNTANSI SMA UNTUK PENINGKATAN MOTIVASI DAN HASIL BELAJAR
}

\author{
Chezaria Danaswari ${ }^{1}{ }^{*}$, Abdul Gafur 1 \\ 1Universitas Negeri Yogyakarta \\ 1J1. Colombo No. 1, Depok, Sleman 55281, Yogyakarta, Indonesia \\ * Corresponding Author. Email: chezaria.d@gmail.com
}

\begin{abstract}
Abstrak
Penelitian ini bertujuan menghasilkan multimedia pembelajaran berbasis web untuk mata pelajaran Akuntansi SMA, dan mengetahui hasil belajar dan motivasi belajar dengan menggunakan multimedia pembelajaran berbasis web yang dikembangkan. Model pengembangan multimedia web menggunakan Alessi and Trollip melalui tiga tahapan, yakni perencanaan, desain, dan pengembangan. Uji coba evaluasi produk terdiri atas: evaluasi formatif meliputi uji alpha, yakni validasi produk oleh dua ahli materi dan dua ahli media, dan uji beta kesan siswa. Serta evaluasi sumatif meliputi uji coba hasil belajar dan motivasi belajar. Hasil penelitian menunjukkan: (1) produk yang dihasilkan berupa website studioakuntansi.com layak digunakan dalam kegiatan pembelajaran berdasarkan hasil penilaian ahli materi, ahli media dan uji beta dengan skor 4,23 (kategori sangat baik); (2) peningkatan skor rata-rata pada pretest dan posttest hasil belajar seluruh siswa sebesar 0,43 (kategori sedang), peningkatan skor rata-rata pada pretest dan posttest motivasi belajar seluruh siswa sebesar 0,38 (kategori sedang). Terdapat peningkatan hasil belajar dan motivasi belajar siswa setelah menggunakan multimedia pembelajaran Akuntansi berbasis web.

Kata kunci: pengembangan multimedia, pembelajaran berbasis web, multimedia web, pembelajaran Akuntansi
\end{abstract}

\section{WEB BASED TEACHING MULTIMEDIA IN ACCOUNTING SUBJECT OF SENIOR HIGH SCHOOL FOR INCREASING MOTIVATION AND LEARNING OUTCOMES}

\begin{abstract}
The aims of this research are: (1) to produce web based teaching multimedia for accounting subject of senior high school (2) to find out the learning outcome and motivation by using web based teaching multimedia. The development of web based multimedia used Alessi and Trollip model consisting of three main phases: planning, design, developing. The product testing was held on: formative evaluation consisted of alpha testing involving validation by two subject material experts and two media experts, and beta testing of learners' reaction, and sumative evaluation consisted of students' learning outcome and motivation testing. The results of the research showed that: (1) the developed product was studioakuntansi.com website consisting of web based teaching multimedia in the accounting subject feasible to be used in classroom teaching and learning processes, based on the assessment by the subject material experts, media experts and also from the beta testing with the score of 4.23 (very good category), (2) the average gain score on the pretest and posttest of all students' outcome was 0.43 (middle category), and the average gain score on the pretest and posttest of all students' motivation was 0.38 (middle category). There was an increase on the students' learning outcome and motivation after the use of the developed multimedia for accounting subject of senior high school.
\end{abstract}

Keywords: multimedia development, web based learning, multimedia web, accounting subject

Permalink/DOI: http://dx.doi.org/10.21831/jitp.v5i2.15543 


\section{Pendahuluan}

Teknologi informasi dan komunikasi saat ini telah berkembang semakin pesat seiring dengan adanya proses globalisasi. Dalam dunia pendidikan, perkembangan teknologi informasi mempunyai dampak yang positif. Pendidikan yang tadinya berperan sebagai dependent variable kini bergeser ke arah sebaliknya. Ketersediaan teknologi informasi dan komunikasi telah memungkinkan masyarakat pendidikan menjadi lebih cerdas dan melek teknologi informasi (Warsita, 2006, p. 70). Jarak dan waktu tidak lagi menjadi masalah yang berarti untuk mendapatkan ilmu pengetahuan. Derasnya berbagai arus informasi yang masuk melalui proses globalisasi menjadikan masyarakat menjadi semakin kompetitif, terutama dalam segi kualitas sumber daya manusia. Untuk mengantisipasi hal tersebut, dunia pendidikan perlu mempersiapkan sumber daya manusia yang kompeten agar mampu bersaing dalam dunia global.

Kurikulum di Sekolah Menengah Atas (SMA), termasuk di dalamnya mata pelajaran Akuntansi, memuat sejumlah kompetensi yang cukup kompleks. Mata pelajaran Akuntansi merupakan bagian dari mata pelajaran ekonomi yang diselenggarakan di Sekolah Menengah Atas pada mata jurusan IPS dan diberikan sejak siswa duduk di kelas XI IPS. Secara umum, ruang lingkup mata pelajaran Akuntansi terdiri atas beragam bahan kajian yang memiliki karakteristik cukup unik, mulai dari analisis sistem informasi hingga penyusunan laporan keuangan (Departemen Pendidikan Nasional, 2009, p. 5). Secara umum, di dalam Akuntansi tercakup konsep-konsep mengenai sistem pencatatan transaksi keuangan suatu lembaga ekonomi atau perusahaan yang digunakan untuk menghasilkan suatu informasi yang berkenaan dengan pengambilan keputusan.

Dalam proses pembelajaran Akuntansi, pembahasan tiap materi Akuntansi, baik yang bersifat konseptual maupun prosedural, harus dilaksanakan secara tuntas dan sistematis (Departemen Pendidikan Nasional, 2009, p. 11). Ketuntasan dalam penguasaan konsep-konsep Akuntansi merupakan suatu prasyarat mutlak sebelum dilaksanakan pembahasan materi selanjutnya. Hal ini dikarenakan sifat dari materi Akuntansi yang saling terkait dan berkesinambungan satu dengan lainnya. Oleh sebab itu, siswa harus benar-benar memahami dan menguasai setiap materi yang telah diajarkan oleh guru. Kondisi ideal tersebut dapat tercipta apabila didukung dengan partisipasi yang optimal, baik dari sisi guru dalam menggunakan metode dan media pembelajaran, maupun dari partisipasi aktif siswa.

Berdasarkan pengamatan yang dilakukan oleh peneliti di SMA Negeri 2 Yogyakarta kelas XI IPS, kondisi ideal pembelajaran untuk mata pelajaran Akuntansi belum sepenuhnya dapat tercipta. Secara umum jumlah pertemuan untuk mata pelajaran Akuntansi SMA kelas XI program IPS adalah 3 jam pelajaran per minggu, dengan ruang lingkup materi meliputi 8 materi pokok pembahasan. Selama proses pembelajaran berlangsung, guru Akuntansi menggunakan metode pembelajaran ceramah dengan diselingi tanya jawab kepada siswa, serta penerapan metode diskusi untuk materi tertentu yang bersifat konseptual.

Penggunaan ceramah sebagai salah satu metode pemaparan materi Akuntansi sudah tepat karena siswadapat dengan mudah memahami materi Akuntansi yang merupakan hal baru bagi mereka. Melalui penggunaan metode dan media pembelajaran yang tepat, perspektif pemahaman materi dan keterampilan Akuntansi siswa dapat terbangun dengan baik dan terstruktur. Untuk membantu pemahaman siswa terhadap materi, guru menggunakan media tekstual seperti LKS (Lembar Kerja Siswa) dan buku paket yang memuat materi Akuntansi yang diajarkan. Selain itu, digunakan pula media presentasi power point agar proses pembelajaran tidak membosankan. Namun pemanfaatan media tersebut sebagai sarana pendukung proses pembelajaran di kelas dirasa masih sangat kurang. Penggu- 
naan berbagai media pendukung seperti buku tekstual dan slide power point belum mampu memfasilitasi kebutuhan siswa di dalam proses pembelajaran Akuntansi.

Terbatasnya media pembelajaran yang inovatif dan interaktif di dalam mata pelajaran Akuntansi menjadikan proses pembelajaran menjadi monoton. Timbal balik atau feedback antara siswa dengan media pembelajaran yang ada sangatlah minim. Hal itu dapat terlihat dari sikap siswa cenderung pasif dan jenuh dengan kegiatan pembelajaran yang berpusat pada guru (teacher centered learning). Selain itu, siswa diketahui kurang termotivasi untuk mempelajari kembali materi Akuntansi yang telah diajarkan. Hal ini dibuktikan dari hasil wawancara pendahuluan yang telah dilakukan pada siswa kelas XI IPS SMA Negeri 2 Yogyakarta.

Berdasarkan analisis kebutuhan yang dilakukan oleh peneliti pada saat prasurvei, diperoleh data bahwa sebagian besar siswa hanya mempelajari kembali materi Akuntansi ketika diadakan ulangan harian, quiz, ujian mid semester maupun ujian semester. Hal tersebut menjadikan siswa menjadi mudah lupa dan kurang memahami konsep-konsep Akuntansi. Keterbatasan guru dalam memantau kegiatan belajar siswa turut membuat permasalahan tersebut menjadi berlarut-larut. Setelah jam sekolah usai, siswa bertanggung jawab melaksanakan kegiatan belajarnya secara mandiri di rumah, namun terdapat gangguan belajar di rumah seperti TV, game, dan aktivitas lainnya.

Keterbatasan pengawasan tersebut membawa dampak pada kurang optimalnya hasil belajar siswa pada mata pelajaran Akuntansi. Diketahui dari hasil studi dokumentasi (nilai raport) bahwa sebagian besar siswa memperoleh nilai kurang dari nilai kriteria ketuntasan minimal (KKM) yang telah ditetapkan. Nilai KKM untuk mata pelajaran Akuntansi di SMA Negeri 2 Yogyakarta adalah 7,50 sedangkan rata-rata hasil belajar siswa adalah sebesar 6,65. Dengan kata lain, data tersebut menunjukkan bahwa kompetensi yang seharusnya dimi- liki siswa belum sepenuhnya tercapai, padahal pencapaian kompetensi dasar dalam kegiatan pembelajaran merupakan hal mutlak yang harus dipenuhi oleh siswa.

Jika kondisi tersebut tidak ditindaklanjuti maka hasil belajar siswa akan menjadi kurang maksimal, bahkan cenderung rendah sehingga tujuan pembelajaran yang diharapkan tidak dapat tercapai. Oleh karena itu, diperlukan suatu media pembelajaran yang menarik dan interaktif, dan dapat diakses siswa dalam rangka belajar mandiri.

Salah satu bentuk media tersebut adalah multimedia pembelajaran dengan basis web. Hal itu didasari atas fakta bahwa web, yang merupakan perantara antara internet dengan pemakainya, dapat diakses oleh user kapanpun dan dimanapun, serta telah banyak dipadukan dengan multimedia yang dibangun dengan menggunakan macromedia flash, yaitu aplikasi yang memiliki fungsi untuk membuat animasi serta situs web yang sangat atraktif dan interaktif. Multimedia pembelajaran berbasis web dapat mendorong siswa untuk belajar lebih mandiri, dan mengubah teacher-centred learning menjadi student centred learning sehingga dapat menimbulkan motivasi belajar mandiri yang sangat besar dalam diri siswa (Patmanthara, 2007, pp. 65-67).

Pembelajaran berbasis web atau proses pembelajaran on-line pada dasarnya dilakukan dengan memanfaatkan jaringan internet atau intranet, sehingga sering disebut juga dengan e-learning. Salah satu bentuk media yang dapat mendukung terlaksananya proses e-learning tersebut adalah multimedia pembelajaran berbasis web yang memuat berbagai aplikasi dan materi pembelajaran yang terhubung secara online dengan internet serta dilengkapi dengan berbagai fasilitas lain yang memudahkan interaksi antara peserta didik atau pengguna (user) dengan pengajar (Prasojo, 2011, p. 207).

Boulton 2008 (pp. 11-18) menyatakan penggunaan e-learning selama 2 tahun di tingkat pendidikan menengah dengan siswa usia 14-16 tahun di Inggris menunjuk- 
kan e-learning dapat memberikan dukungan yang lebih baik untuk siswa yang mempunyai kemampuan kurang, meningkatkan respon keterlibatan siswa pada proses pembelajaran, memberikan kesempatan percepatan (akselerasi) belajar bagi siswa yang cerdas dan berbakat, serta mengembangkan kemampuan belajar siswa secara mandiri melalui pengalaman belajar.

Keunggulan pembelajaran berbasis web atau e-learning juga diungkapkan oleh Mu'arif \& Surjono (2016, p. 11) dalam penelitiannya dimana diketahui bahwa elearning atau pembelajaran berbasis web terbukti memiliki efek positif terhadap hasil belajar berupa meningkatnya kompetensi kognitif dan pemahaman konsep. Hal serupa juga diungkapkan oleh Januarisman \& Ghufron (2016, p. 16) Januarisman (2016, p.16) bahwa penggunaan media pembelajaran secara online dalam pembelajaran dapat meningkatkan kompetensi peserta didik. Selain itu, tingginya efektivitas web terhadap hasil pembelajaran siswa diperkuat oleh peneltian yang dilakukan oleh Purmadi \& Surjono (2016, p. 11), bahwa pengembangan bahan ajar berbasis web terbukti efektif dalam meningkatkan respon siswa dan hasil belajar siswa.

Dengan didukung ketersediaan jaringan internet dan perangkat komputer yang dimiliki setiap siswa, maka peneliti memutuskan mengembangkan suatu multimedia pembelajaran berbasis web untuk mata pelajaran Akuntansi kelas XI IPS Sekolah Menengah Atas (SMA) dalam upaya meningkatkan motivasi dan hasil belajar siswa.

Dalam penelitian pengembangan ini dihasilkan suatu multimedia pembelajaran Akuntansi dengan basis web yang dapat diakses melalui alamat portal/URL: www.studioakuntansi.com. Multimedia pembelajaran berbasis web ini dikembangkan melalui bahasa pemograman PHP menggunakan software Notepad ++ , dengan tampilan yang disusun dari kode HTML dan CSS template, serta Adobe Flash CS3.

Berdasarkan latar belakang masalah, maka tujuan penelitian ini adalah (1) menghasilkan suatu produk multimedia pembelajaran berbasis web untuk mata pelajaran Akuntansi SMA, (2) mengetahui hasil belajar siswa dan (3) mengetahui motivasi belajar siswa setelah menggunakan multimedia pembelajaran berbasis web.

\section{Metode Penelitian}

Penelitian ini merupakan penelitian pengembangan yang bertujuan mengembangkan suatu multimedia pembelajaran berbasis web pada mata pelajaran Akuntansi SMA. Orientasi dari penelitian pengembangan ini berupa portal e-learning Akuntansi yang dikembangkan dengan pemrograman $P H P$.

Model yang digunakan dalam pengembangan produk ini adalah model penelitian dan pengembangan yang diadopsi dari Alessi \& Trollip (2001, pp. 410-413) yang disesuaikan dengan tujuan penelitian.

Prosedur pengembangan dan desain multimedia pembelajaran ini terdiri atas 3 atribut (three attributs) yang melengkapi 3 fase (three phases) pengembangan multimedia. Tiga atribut tersebut adalah standard, on going evaluation, dan project management. Sedangkan tiga fase pengembangan multimedia terdiri atas: (1) planning (perencanaan), (2) design (desain), dan (3) development (pengembangan). Ketiga atribut berperan sebagai pengontrol atau acuan dalam setiap pelaksanaan fase pengembangan dan terus diterapkan selama proses pengembangan multimedia berlangsung.

Fase perencanaan meliputi: mendefinisikan ruang lingkup kajian (define the scope), mengidentifikasi karakteristik siswa (identify learner characteristics), menentukan batasan/ketentuan multimedia web (establish constraints), menentukan standar desain multimedia (produce a style manual), menentukan dan mengumpulkan sumber (determineEcollect resources), melakukan brainstorming (conduct initial brainstorming).

Fase desain meliputi: melakukan analisis konsep dan tugas (conduct task and concept analysis), dan membuat flowchart dan storyboard desain multimedia pembelajaran. 
Fase pengembangan meliputi: menyiapkan teks materi (prepare the text), membangun multimedia pembelajaran dengan basis web PHP (write program code and create the graphics), menggabungkan tiap-tiap komponen media web (assemble the pieces), menyiapkan materi-materi pendukung (prepare support material), evaluasi formatif melalui dua tahap, yaitu uji alpha dan uji beta, dan tahap terakhir yakni evaluasi sumatif.

Desain uji coba dalam mengembangkan multimedia pembelajaran web, uji coba produk yang dilakukan dibedakan menjadi dua jenis, yaitu uji coba untuk mengetahui kelayakan produk multimedia web dan uji coba untuk mengetahui efektivitas produk multimedia web. Mengetahui kelayakan produk, dilakukan evaluasi formatif yang terdiri atas uji alpha (validasi ahli materi dan ahli media), serta uji beta (uji coba terhadap siswa). Data yang diperoleh kemudian dianalisis dan digunakan dalam memperbaiki atau menyempurnakan produk yang dikembangkan. Dengan proses uji coba ini diharapkan kualitas media yang dikembangkan menjadi lebih baik. Uji efektivitas produk dilakukan melalui evaluasi sumatif dan dilaksanakan setelah program selesai dievaluasi secara formatif dan direvisi. Uji efektivitas ini dilakukan untuk mengetahui apakah ada gain score atau peningkatan motivasi dan pencapaian hasil belajar siswa setelah menggunakan produk yang dikembangkan.

Subjek uji coba di dalam penelitian ini (uji evaluasi sumatif) adalah siswa kelas XI IPS 2 SMA Negeri 2 Yogyakarta tahun ajaran 2011/2012. Jumlah subjek uji coba di kelas XI IPS 2 adalah berjumlah 30 orang. Sedangkan untuk uji formatif pada tahap uji beta, subjek uji coba adalah siswa kelas XI IPS 1 sebanyak 9 orang. Pemilihan subjek uji coba didasarkan atas kemampuan akademik siswa yang diketahui dari dokumentasi hasil belajar siswa atau nilai raport.

Ada 2 jenis data yang diambil dalam penelitian ini, yakni: (1) data kualitatif, diperoleh dari data hasil observasi dan wawancara siswa, dan dari data hasil validasi ahli materi, ahli media, dan angket kesan siswa terhadap multimedia pembelajaran web yang dikembangkan, (2) data kuantitatif, diperoleh dari data hasil angket kesan siswa terhadap produk multimedia yang dikonversikan ke dalam skala angka 5, dan dari nilai pretest dan post test hasil belajar siswa.

Menghasilkan produk pengembangan yang berkualitas, diperlukan instrumen berkualitas yang mampu menggali apa yang ingin diketahui dalam proses penelitian ini. Instrumen yang digunakan terbagi menjadi 2 jenis yakni: (1) instrumen utama, terdiri atas instrumen angket, bertujuan menilai kualitas multimedia pembelajaran berbasis web yang dikembangkan baik dari segi materi maupun media yang divalidasi oleh ahli materi, ahli media, serta oleh siswa; serta tes hasil belajar Akuntansi (uji kompetensi materi Akuntansi), bertujuan mengetahui seberapa jauh peningkatan hasil belajar kognitif dengan menggunakan multimedia web. Instrumen mengukur motivasi juga diperlukan dalam penelitian ini. Melalui instrumen tes dapat diketahui skor hasil belajar prestest dan post test siswa. (2) instrumen penunjang, berupa lembar observasi, dimana observasi dilakukan oleh peneliti dan dibantu oleh guru mata pelajaran Akuntansi dan berfungsi menggali data mengenai karakteristik siswa guna mencapai ketepatan rancangan dan produk yang dihasilkan; serta pedoman wawancara, digunakan sebagai alat pengumpul data dari siswa, guru Akuntansi, ahli materi dan media, sehubungan dengan analisis kebutuhan yang diperlukan pengembangan produk. Melalui wawancara, pengembang produk dapat memperoleh informasi tambahan berupa saran, kritik, dan masukan di luar data angket yang bermanfaat bagi kualitas produk saat uji beta.

Instrumen penelitian berupa angket validasi produk maupun angket motivasi belajar, disusun dan dikembangkan peneliti berdasarkan teori karakteristik multimedia. Sedangkan instrumen tes hasil belajar disusun berdasarkan standar isi kurikulum pada mata pelajaran Akuntansi. 
Kriteria penilaian kualitas materi multimedia web pada instrumen validasi materi mengadaptasi Walker \& Hess (Arsyad, 2009, pp. 175-176), meliputi: (1) komponen aspek pembelajaran (pendahuluan SKKD, penyajian materi, evaluasi/tes); (2) komponen aspek isi (materi, contoh soal, visualisasi, bahasa, rumusan soal).

Sedangkan kriteria penilaian kualitas media multimedia web pada instrumen validasi media diadaptasi dari Alessi \& Trollip (2001, pp. 382-397), meliputi: (1) komponen aspek tampilan (teks atau huruf, warna, gambar/grafis, animasi, screen design, navigation); (2) komponen aspek aksesibilitas/teknis program (interactivity, privacy and storing data, aksesibilitas dan stability, compatibility media, non-web contact information, communication features, program boundaries).

Kriteria penilaian kesan siswa terhadap multimedia web terkait aspek kemenarikan media, meliputi komponen teks atau huruf, warna, gambar, screen design, materi \& test, communication features, user interface, dan bahasa.

Sedangkan kriteria instrumen motivasi belajar siswa, diadaptasi dari kajian ciri-ciri motivasi belajar (Sardiman, 2003, p. 83), meliputi: komponen motivasi instrinsik, minat belajar, tertarik pada hal baru, dan etos belajar.

Validitas instrumen dalam penelitian ini meliputi validitas teori dan validitas empirik. Validitas teori digunakan dalam penyusunan kisi-kisi butir lembar penilaian untuk ahli media, ahli materi, dan siswa, serta dalam penyusunan kisi-kisi butir angket kesan dan motivasi belajar siswa. Sebelum divalidasi, kisi-kisi instrumen dikonsultasikan terlebih dahulu kemudian divalidasi oleh 1 orang validator instrumen. Instrumen yang divalidasi meliputi instrumen angket bagi ahli media, ahli materi, dan kesan siswa.

Sedangkan validitas empiris digunakan untuk memvalidasi instrumen butir soal tes hasil belajar siswa. Jenis soal yang digunakan dalam tes hasil belajar Akuntansi, baik saat pretest dan post test adalah jenis soal obyektif/pilihan ganda dengan 5 opsi pilihan jawaban. Validasi soal tes hasil belajar dilakukan dengan mengujicobakan terlebih dahulu butir soal tes pada siswa yang bukan merupakan subjek penelitian ini. Data tes hasil belajar yang diperoleh kemudian dianalisis menggunakan program komputer Iteman 3.00 dalam mengetahui tingkat kevalidan tiap butir soal.

Setelah proses validasi tersebut, diperoleh instrumen soal tes hasil belajar yang valid sehingga diperoleh data sesuai dengan apa yang ingin diketahui oleh peneliti. Mengetahui validitas butir soal tes hasil belajar dalam suatu uji coba, dapat dilihat dari besarnya skor korelasi point biserial dari setiap butir soal tersebut (Ebel \& Frisbie, 1991, p. 232). Kriteria yang digunakan dalam menentukan validitas (baik tidaknya) butir soal dirangkum pada Tabel 1.

Tabel 1. Kriteria Indeks Point Biserial

\begin{tabular}{cc}
\hline Indeks Point Biserial & Kategori \\
\hline $0,40 \leq p b$ & Sangat Baik \\
$0,30 \leq p b \leq 0,39$ & Baik \\
$0,20 \leq p b \leq 0,29$ & Cukup \\
$p b \leq 0,19$ & Jelek \\
\hline
\end{tabular}

Kriteria indeks point biserial di atas selanjutnya digunakan dalam menentukan status butir soal dalam sebuah instrumen tes hasil belajar, yaitu: $\mathrm{pb} \leq 0,19=$ butir soal jelek (poor), tidak boleh dipakai. Indeks $p b$ : $0,20-0,29=$ butir soal cukup (satisfactory), sebaiknya diperbaiki atau direvisi. Indeks $p b: 0,30-0,39=$ butir soal baik (good), dapat dipakai ataupun direvisi. Indeks $0,40 \leq \mathrm{pb}=$ butir soal sangat baik (excellent), dapat dipakai tanpa perlu direvisi.

Sedangkan dalam menguji reliabilitas instrumen perangkat soal, Suatu perangkat soal disebut reliabel atau andal apabila soal tersebut diujikan pada subjek yang sama dan dengan waktu yang berbeda memberikan hasil yang tetap sama (konsisten). Dalam pengujian reliabilitas perangkat soal, suatu instrumen dinyatakan layak dipakai atau diterima apabila memiliki koefisisen reliabilitas $(\mathrm{r} 11) \geq 0,70$ (Sukardjo, 2005, p. 68). Dengan demikian, suatu perangkat soal 
tes hasil belajar minimal me-miliki nilai koefisien sebesar 0,70 supaya dapat dikatakan reliabel dalam pengujian. Hasil analisis uji validitas dan reliabilitas terhadap perangkat soal tes hasil belajar pada mata pelajaran Akuntansi kelas XI IPS penelitian ini menggunakan program Iteman.

Data yang telah terkumpul dianalisis dalam mengetahui kualitas dari produk multimedia web yang dihasilkan. Data-data evaluasi formatif tentang produk yang dikembangkan, yakni mengenai kualitas tampilan, kualitas penyajian materi dan pemberian motivasi oleh multimedia pembelajaran web sebagai pertimbangan dalam merevisi produk, sedangkan mengetahui efektivitas produk dalam meningkatkan motivasi dan hasil belajar siswa dapat dilihat dengan cara membandingkan rerata nilai pre test dan post test.

Pada evaluasi formatif, pengumpulan data dilakukan dengan cara memberikan angket dan wawancara langsung kepada ahli media dan ahli materi. Data yang diperoleh dari hasil penilaian instrument dan wawancara dengan ahli media dan ahli materi dirangkum dalam tabel yang tidak diubah menjadi data kuantitatif. Hal tersebut disebabkan karena ahli media dan ahli materi hanya memberikan saran dan masukan terkait produk multimedia web yang dikembangkan. Saran dan masukan yang diberikan oleh ahli media dan ahli materi tersebut kemudian dipergunakan sebagai acuan perbaikan produk yang sedang dikembangkan sebelum produk tersebut diujicobakan kepada siswa di kelas.

Angket juga diberikan kepada 9 orang siswa yang ditunjuk sebagai responden dengan tujuan supaya mengetahui kesan siswa terhadap produk multimedia pembelajaran web. Data penilaian siswa berupa kesan siswa terhadap multimedia serta data motivasi belajar siswa, dirangkum dalam bentuk angket skala sikap siswa. Hasil penilaian angket sikap siswa tersebut berupa data kualitatif kemudian diubah menjadi skala angka dengan menggunakan skala Likert.
Saat mengukur bobot atau nilai dari pernyataan sikap siswa, data kualitatif tersebut dikonversikan ke dalam skala angka, yakni menjadi skala angka 5 .

Tabel 2. Konversi Nilai dengan Skala 5

\begin{tabular}{|c|c|c|c|}
\hline Nilai & Kategori & Rumus & Perhitungan \\
\hline A & Sangat & $X>\overline{X \imath}+1,80 \mathrm{SB} i$ & $X>4,2$ \\
\hline B & $\begin{array}{l}\text { Tinggi } \\
\text { Tinggi }\end{array}$ & $\begin{array}{c}\overline{X_{\imath}}+0,6 \mathrm{SB} i<X \leq \overline{X_{\imath}}+ \\
1,80 \mathrm{SB} i\end{array}$ & 4,2 \\
\hline C & Sedang & $\begin{array}{c}\overline{X l}-0,6 \mathrm{SB} i<X \leq \bar{X}{ }^{+}+ \\
0,6 \mathrm{SB} i\end{array}$ & $2,6<X \leq 3,4$ \\
\hline D & Kurang & $\begin{array}{c}\overline{X l}-1,80 \mathrm{SB} i<X \leq \overline{X l}- \\
0,60 \mathrm{SB} i\end{array}$ & $1,8<X \leq 2,6$ \\
\hline E & $\begin{array}{l}\text { Sangat } \\
\text { Kurang }\end{array}$ & $X \leq \overline{X l}-1,80 \mathrm{SB} i$ & $X \leq 1,8$ \\
\hline
\end{tabular}

Keterangan:

$\overline{X \iota} \quad$ : rerata skor ideal $: \frac{1}{2}$ (skor maksimal ideal + skor minimal ideal)

$\mathrm{Sbi}$ : simpangan baku skor ideal : $\frac{1}{6}$ (skor maksimal ideal - skor minimal ideal)

$X$ : skor aktual

Dari perbandingan skor di atas diperoleh standar kualitas produk multimedia pembelajaran dengan rincian sebagai berikut: (1) Produk yang dikembangkan dinyatakan sangat baik (A) bila rata-rata skor yang diperoleh antara 4,20 sampai dengan 5,00; (2) Produk yang dikembangkan dinyatakan baik (B) bila rata-rata skor yang diperoleh antara 3,41 sampai dengan 4,20; (3) Produk yang dikembangkan dinyatakan cukup baik (C) bila rata-rata skor yang diperoleh antara 2,61 sampai dengan 3,40; (4) Produk yang dikembangkan dinyatakan kurang baik (K) bila rata-rata skor yang diperoleh antara 1,8 sampai dengan 2,60; (5) Produk yang dikembangkan dinyatakan sangat kurang (SK) bila rata-rata skor yang diperoleh antara 1 sampai dengan 1,80. (Sukarjo, 2005, p. 52).

Pada evaluasi sumatif, data yang diperoleh berupa: data angket motivasi belajar dan data hasil belajar siswa dari nilai pre- 
test dan posttest. Kedua data pada evaluasi sumatif dianalisis sehingga dapat diketahui apakah produk yang dihasilkan layak dan efektif digunakan dalam pembelajaran, serta dapat membangkitkan motivasi dan hasil belajar siswa. Data angket diubah menjadi skala angka yang menggunakan skala Likert, sedangkan data pretest dan posttest dibandingkan untuk melihat apakah ada peningkatan hasil belajar siswa.

Peningkatan hasil belajar siswa sebelum dan sesudah menggunakan multimedia diperhitungkan dengan rumus (Ngain) yang ditentukan berdasarkan rata-rata gain skor yang dinormalisasi (g) yaitu perbandingan dari skor gain. Skor gain adalah skor yang diperoleh siswa dari pretest dan post test. Sedangkan skor gain maksimum, yaitu skor gain tertinggi yang diperoleh siswa. rata-rata gain yang dinormalisasi (N-gain) (Hake, 1998, p. 2) dinyatakan oleh persamaan sebagai berikut:

Keterangan:

$$
g=\frac{S \text { post }-S \text { pre }}{S \text { maks }-S \text { pre }}
$$

S post : Rata-rata Skor Post Test

$S$ pre : Rata-rata Skor Pretest

$S$ maks: Skor Maksimal

Nilai yang diperoleh kemudian diinterpretasikan ke dalam tabel klasifikasi nilai Gain (Hake, 1998, p.3) dengan kriteria sebagai berikut:

Tabel 3. Klasifikasi Nilai Gain

\begin{tabular}{cc}
\hline Nilai & Klasifikasi \\
\hline$(\mathrm{N}-$ gain $) \geq 0,7$ & Tinggi \\
$0,7<(\mathrm{N}$-gain $) \geq 0,3$ & Sedang \\
$(\mathrm{N}$-gain $)<0,3$ & Rendah \\
\hline
\end{tabular}

\section{Hasil Penelitian dan Pembahasan}

Hasil Perencanaan

\section{Mendefinisikan Ruang Lingkup Kajian (Define} the Scope)

Dari hasil observasi, peneliti memutuskan memilih materi Struktur Dasar Akuntansi sebagai ruang lingkup kajian multimedia web Akuntansi. Kompetensi
Struktur Dasar Akuntasi terdiri dari 4 materi utama, yaitu: (1) Penggolongan transaksi keuangan, (2) Penggolongan akun, (3) Persamaan Akuntansi, (4) Laporan keuangan. Keempat materi tersebut merupakan materi utama yang menjadi dasar konseptual dalam memahami Akuntansi secara menyeluruh dan sebagai pengetahuan dasar menuju materi Akuntansi selanjutnya.

\section{Mengidentifikasi Karakteristik Siswa (Identify Learner Characteristics).}

Peserta didik SMA berada pada periode perkembangan tahap operasional formal (umur 11/12-18 tahun). Pada usia ini, pola berpikir siswa telah berkembang menjadi lebih logis dan mampu berpikir abstrak. Berdasarkan pengamatan peneliti, siswa kelas XI telah mampu menafsiran suatu konsep, mengembangkan hipotesis, dan menarik kesimpulan atas penjelasan yang diberikan guru. Secara umum keunikan dari kelas XI IPS 2 adalah sebagian besar siswanya sangat menyukai hal-hal yang bersifat terkini dan canggih. Siswa SMA terbiasa belajar secara mandiri menggunakan internet dalam mengetahui hal-hal terkini. Hal ini terlihat dari banyaknya siswa yang menggunakan notebook dan handphone sebagai sarana dalam mencatat materi yang diberikan guru serta menggunakan internet. Berdasarkan observasi karakteristik tersebut, peneliti memutuskan mengembangkan sebuah multimedia pembelajaran Akuntansi dengan basis web yang sesuai dengan karakteristik peserta didik pada tahap operasional formal serta dapat memfasilitasi kebutuhan belajar siswa.

\section{Menentukan Batasan atau Ketentuan Multimedia Web (Establish Constraints).}

Dari segi pengembang: Spesifikasi hardware yang harus dimiliki dalam mengembangkan multimedia web yaitu: Komputer PC/Laptop/Notebook (Pentium Processor, RAM $1 \mathrm{~Gb}$, Resolusi minimal 1366 x 768, VGA minimal 32 bit, Speaker, Operation System: Windows XP, Vista, Windows 7,MAC OS); Modem dan jaringan internet dengan bandwidth minimal 256 
kbps. Software yang digunakan dalam pengembangan multimedia, antara lain web browser seperti Mozilla Firefox, Opera Browser, dan Google Chrome, Adobe Flash CS 3, Adobe Photoshop CS3, Notepad++, Corel Draw X4, Adobe Illustrator. Dari segi User atau pengguna: spesifkasi yang harus dimiliki user dalam mengakses multimedia Akuntansi berbasis web ini adalah: komputer PC/Laptop/Noteboo k(Pentium Processor, RAM 1 Gb, Resolusi minimal 1366 × 768, VGA minimal 32 bit, Speaker, dan Operation System: Windows XP, Vista, Windows 7,MAC OS); Modem dan jaringan internet dengan bandwidth minimal 256 kbps; dilengkapi dengan web browser seperti Mozilla Firefox, Opera Browser, Google Chrome; dan Adobe Flash.

\section{Menentukan Standar Desain Multi-Media (Produce a Style Manual).}

(1) Layout website multimedia Akuntansi ini terdiri atas 6 menu utama, yaitu Homepage, Course-page, Test-page, Info-page, Forum-page, dan Log-in page. Khusus pada bagian course atau materi serta test-page, desain layout web dibuat menyerupai bentuk sebuah buku, dengan tujuan dapat membangkitkan suasana belajar bagi user. (2) Jenis huruf yang digunakan pada teks adalah theme font Courier New dan Pristine, dengan ukuran huruf 12 pt pada teks materi dan 16 pt pada teks homepage dan judul materi. (3) Tema yang dipilih dalam desain template website dan desain multimedia pembelajaran Akuntansi adalah modern futuristik dengan desain template minimalis tanpa penggunaan icon atau karakter yang mencolok. (4) Warna dasar yang digunakan dalam template website maupun mutimedia Akuntansi adalah warna biru muda, hitam dan putih. (5) Logo dan Gambar yang dikembangkan terdiri dari huruf " $S$ " dan " $A$ " merupakan ciri khas dari website agar mudah diinget oleh siswa. (6) Pengaplikasian komponen animasi pada website ini ditampilkan melalui program animasi jQuery. (7) Tombol navigasi dalam multimedia berbasis web ini dibuat se- menarik mungkin dengan mengedepankan tema modern futuristik.

\section{Menentukan dan Mengumpulkan Sumber (Determine and Collect Resources)}

Materi Akuntansi yang dipilih peneliti berasal dari dua sumber, yakni buku teks pelajaran Akuntansi dan e-book atau buku sekolah elektronik (BSE) mata pelajaran Akuntansi kelas XI yang dikembangkan dan dipublikasikan secara resmi oleh Kementerian Pendidikan dan Kebudayaan.

\section{Melakukan Brainstorming (Conduct Initial Brainstorming)}

Guru pengampu mata pelajaran Akuntansi kelas XI IPS menyarankan supaya menambahkan materi sejarah Akuntansi meskipun materi tersebut tidak termasuk dalam materi pengembangan dimaksudkan agar siswa memiliki apersepsi terkait ilmu Akuntansi sebelum memulai pembelajaran konsep dasar Akuntansi menggunakan multimedia web.

Hasil Desain

Melakukan Analisis Konsep dan Tugas

(Conduct Task and Concept Analysis)

Konsep isi atau konten materi multimedia web merujuk pada Standar Kompetensi (SK) yaitu memahami penyusunan siklus Akuntansi Perusahaan Jasa dan Kompetensi Dasar (KD) dari materi Struktur Dasar Akuntansi, dengan 4 materi utama yang menjadi fokus pengembangan materi. Pada menu test-page multimedia web yang berfungsi sebagai sarana latihan siswa, dipilih bentuk tes pilihan ganda dan isian. Sedangkan untuk mengevaluasi hasil belajar siswa baik sebelum dan setelah menggunakan multimedia web, dipilih bentuk instrumen tes pilihan ganda.

Membuat Struktur Desain Multimedia Pembelajaran Berbasis Web (Create Flowcharts and Storyboards)

Flowcharts multimedia pembelajaran Akuntansi berbasis web menggambarkan 
alur dasar atau urutan proses sistem kerja multimedia web ketika diakses oleh user. Pembuatan flowchart diikuti dengan pembuatan storyboard produk multimedia web. Storyboard mencakup desain awal atau rancangan tampilan visual produk sebelum dikembangkan melalui coding program. Dalam tahap ini mulai ditentukan susunan atau tatanan desain menu utama, logo website, tampilan materi dan halaman tes, serta fitur-fitur lainnya.

Hasil Pengembangan

Produk multimedia pembelajaran Akuntansi berbasis web yang dikembangkan oleh peneliti dibangun melalui coding system PHP atau pemrograman $P H P$ dengan bantuan programmer website, menggunakan aplikasi Adobe Flash CS 3, Adobe Photoshop CS3, Notepad++, Corel Draw X4, Adobe Illustrator.

Tahapan awal pengembangan dimulai dengan menyiapkan seluruh teks materi Akuntansi yang telah dikumpulkan sebelumnya dari berbagai sumber agar dirangkum menjadi satu ke dalam format teks multimedia (.txt). Selanjutnya menentukan desain tampilan serta content menu yang ada di dalamnya. Kemudian programmer web memulai proses coding system mengacu pada flowcharts dan storyboards yang telah disusun sebelumnya.

Pada tahap ini pula ditentukan Role Based Access Control (RBAC) atau peran pengguna website. Dalam multimedia web ini, peran pengguna terbagi menjadi 3, yaitu: administrator (pengelola web), teacher (guru mata pelajaran), dan user (siswa atau pengguna umum). Setelah proses coding dan penggabungan tiap komponen media terselesaikan, ditentukan server dan domain website serta dipilihlah nama URL: www.studioakuntansi.com sebagai alamat website yang dikembangkan. Berikut adalah profil tampilan website studioakuntansi.com:

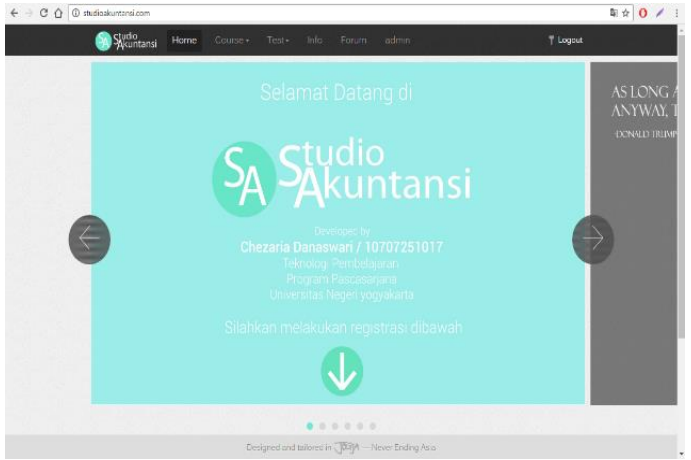

Gambar 1. Tampilan homepage studioakuntansi.com

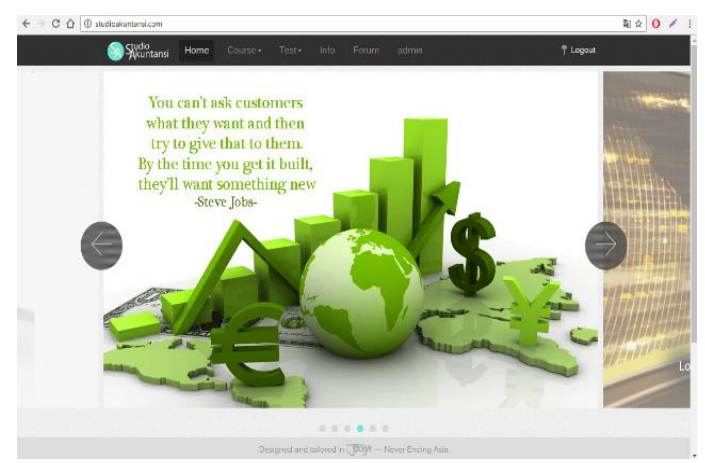

Gambar 2. Tampilan slideshow homepage jQuery

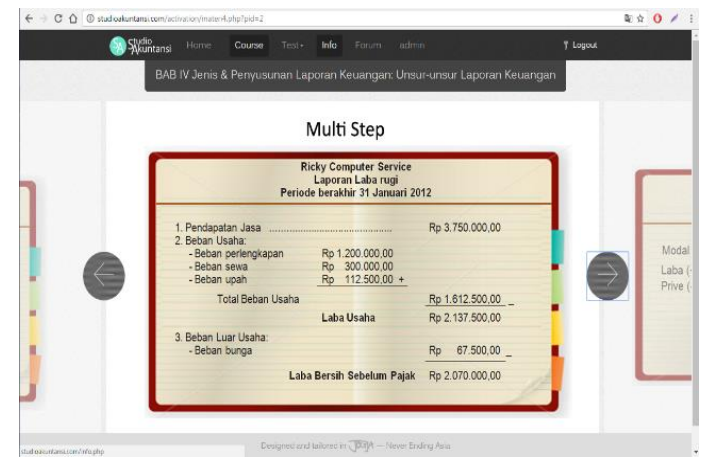

Gambar 3. Tampilan Menu Course Laporan Keuangan

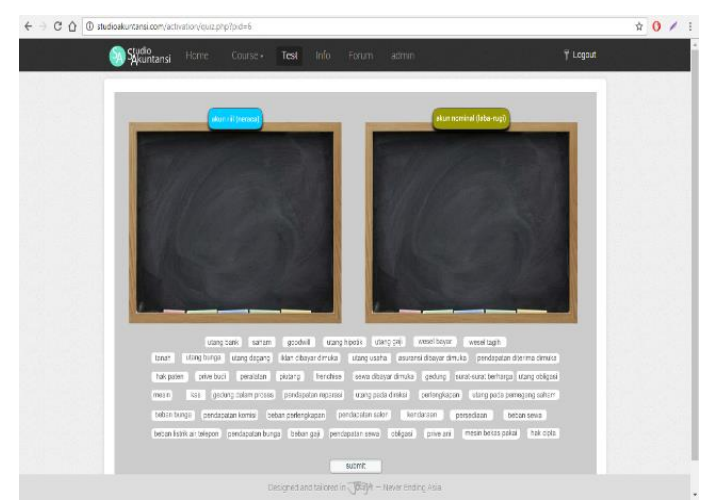

Gambar 4. Menu Test model Drag and Drop 
Hasil Uji Coba Produk

Setelah multimedia pembelajaran Akuntansi berbasis web selesai dikembangkan, tahap selanjutnya adalah mengevaluasi kelayakan produk sebelum digunakan dalam proses pembelajaran. Evaluasi kelayakan produk atau disebut juga evaluasi formatif ini terdiri atas 2 tahap pengujian, yaitu Uji Alpha (validasi produk) dan Uji Beta (kesan user). Pada uji alpha, validasi dilakukan oleh ahli materi Akuntansi dan ahli media. Validasi ahli materi Akuntansi bertujuan mengevaluasi aspek kesesuaian isi materi dan aspek pembelajaran. Validasi materi dilakukan oleh 2 orang validator. Sedangkan validasi media bertujuan mengevaluasi aspek tampilan dan program media, dilakukan oleh 2 ahli media.

Hasil validasi menunjukkan bahwa ditinjau dari aspek pembelajaran dan isi, cakupan materi Akuntansi yang dikembangkan dalam produk multimedia pembelajaran Akuntansi berbasis web dinilai telah memenuhi persyaratan kevalidan materi pembelajaran. Hal tersebut dapat dilihat dari penilaian yang diberikan oleh ahli materi, bahwa seluruh komponen indikator telah dapat terpenuhi dengan baik.

Sedangkan hasil validasi media diketahui bahwa terdapat beberapa komponen media yang belum memenuhi kriteria kevalidan ditinjau dari aspek tampilan maupun dari aspek program/aksesibilitas media Namun secara umum multimedia pembelajaran Akuntansi berbasis web tersebut tetap dapat digunakan dalam proses pembelajaran, hanya saja diperlukan beberapa perbaikan atau revisi sesuai saran dari ahli media agar dapat diperoleh sebuah produk multimedia web yang layak dan valid dari segala aspek. Setelah aspek tersebut diperbaiki, maka diperoleh sebuah multimedia pembelajaran Akuntansi berbasis web yang layak diujicobakan pada siswa.

Uji beta produk multimedia web dilakukan oleh 9 orang siswa dengan kriteria: 3 orang dengan tingkat akademik tinggi, 3 orang tingkat akademik sedang, dan 3 orang dengan tingkat akademik rendah.
Dalam penelitian ini, instrumen penelitian yang digunakan dalam uji beta, yakni angket kemenarikan media dan motivasi belajar siswa. Sebelum uji coba dilakukan, peneliti menjelaskan terlebih dahulu prosedur yang harus dilakukan siswa, yakni siswa harus mendaftar terlebih dahulu sebagai user pada Multimedia Pembelajaran Akuntansi berbasis web ini. Tahapan ini dilakukan dengan cara mengakses alamat portal website www.studioakuntansi.com, kemudian melakukan register akun. Setelah tahapan ini selesai dilakukan, maka siswa dapat memulai pembelajaran dengan multimedia web tersebut, dengan diawali pemberian pretest secara offline atau tes tertulis dalam mengetahui kemampuan awal para siswa.

Setelah pretest dilakukan, siswa kemudian diminta mempelajari, mengamati dan mencermati seluruh isi atau konten website studio Akuntansi. Setelah aktivitas pembelajaran dirasa cukup, peneliti kemudian memberikan post test dengan tes tertulis dalam mengetahui sejauh mana aktivitas pembelajaran siswa. Selain itu, peneliti juga memberikan angket kesan tehadap multimedia web tersebut. Hasil penilaian tersebut diubah menjadi data kuantitatif menggunakan skala Likert.

Hasil analisis data kesan siswa menunjukkan bahwa aspek A (kejelasan teks atau tulisan) memperoleh skor rata-rata 4,44 (kategori sangat baik), aspek B (kombinasi warna pada web) memperoleh skor 3,89 (kategori baik), aspek C (kemenarikan gambar pada web) mendapatkan skor 3,89 (kategori baik), aspek D (tampilan dan penyajian menu) memperoleh skor 4,33 (kategori sangat baik), aspek E (kemudahan memahami materi) mendapatkan skor 3,67 (kategori baik), aspek $\mathrm{F}$ (kemenarikan penyajian materi) memperoleh nilai 4,56 (kategori sangat baik), dan aspek $\mathrm{G}$ (petunjuk penggunaan web) memperoleh skor 4,33 (kategori sangat baik).

Selanjutnya pada aspek $\mathrm{H}$ (kejelasan petunjuk pengerjaan soal) memperoleh skor 4,44 (kategori sangat baik), aspek I (kemudahan mengerjakan soal pada web) memperoleh skor 4,22 (kategori sangat baik), 
aspek J (kemudahan penggunaan fasilitas komunikasi seperti forum diskusi) memperoleh skor 4,11 (kategori baik), aspek K (kemudahan memilih menu pada web) mendapatkan skor 4,33 (kategori sangat baik), aspek M (kemudahan menggunakan multimedia web) mendapatkan skor 4,22 (kategori sangat baik), dan aspek $\mathrm{N}$ (kejelasan bahasa yang digunakan dalam web) memperoleh skor 4,33 (kategori sangat baik). Dari keseluruhan skor tiap indikator kesan siswa terhadap multimedia web, diperoleh skor rerata kualitas multimedia web yakni sebesar 4,23 dengan kategori sangat baik

Sedangkan hasil pretest dan post test siswa pada saat uji coba beta menunjukkan bahwa rata-rata nilai hasil belajar siswa sebelum menggunakan multimedia web adalah sebesar 7,11 dan setelah menggunakan multimedia web adalah sebesar 8,26. Jika dilihat dari nilai KKM pelajaran Akuntansi, dapat diketahui bahwa ada 6 orang siswa yang dinilai belum tuntas pada tahap pretest dan 2 orang siswa pada tahap post test.

Hasil tersebut menunjukkan bahwa terjadi peningkatan (gain score) sebesar 0,40, dimana indeks gain score tersebut termasuk dalam kriteria sedang. Oleh karena itu, dapat disimpulkan bahwa multimedia pembelajaran Akuntansi berbasis web tersebut cukup dapat meningkatkan hasil belajar siswa pada saat diterapkan dalam uji beta

Pada tahap evaluasi sumatif, dilakukan uji coba pembelajaran di kelas dengan menggunakan multimedia pembelajaran Akuntansi berbasis web yang melibatkan 30 orang siswa kelas XI IPS 2 SMA Negeri 2 Yogyakarta. Dilakukan melalui 3 tahap kegiatan, yakni diawali dengan kegiatan pengambilan data pretest dan pemberian angket motivasi belajar siswa, kemudian tahap pelaksanaan kegiatan pembelajaran dengan menggunakan multimedia web, dan diakhiri dengan kegiatan pengambilan data post test dan motivasi belajar siswa.

Pada tahap pertama, siswa diminta melakukan pretest dalam menguji kemampuan awal siswa terkait materi struktur dasar Akuntansi, kemudian siswa diminta mengisi angket motivasi belajar. Tahap kedua, pada di setiap kegiatan pembelajaran Akuntansi di kelas maupun di luar jam sekolah, siswa diminta mengakses, mempelajari materi dan mengerjakan latihan soal yang ada pada website studioakuntansi.com. Tahap terakhir, saat kegiatan pembelajaran seluruh materi telah diselesaikan, siswa diminta melakukan post test dan mengisi angket motivasi belajar siswa.

Data evaluasi sumatif menunjukkan nilai rata-rata pretest siswa adalah 7,08 dengan nilai terendah adalah 4,33 dan nilai tertinggi adalah 8,33. Jumlah siswa yang berhasil tuntas belajar berdasarkan kriteria ketuntasan minimal atau KKM pada tahap pretest adalah sebanyak 18 dari 30 siswa.

Sedangkan pada tahap post test, terdapat 28 siswa yang memiliki nilai melampaui kriteria ketuntasan minimal dalam mata pelajaran Akuntansi. Nilai terendah dan tertinggi yang diperoleh siswa adalah 7,00 dan 9,67 dengan nilai rerata post test sebesar 8,34. Terdapat peningkatan rata-rata nilai sebesar 1,26 atau kenaikan persentase hasil belajar sebesar 17,80\% jika dibandingkan dengan nilai rerata pada saat pretest atau ketika siswa belum menggunakan multimedia pembelajaran Akuntansi berbasis web.

Berdasarkan peningkatan nilai hasil belajar tersebut, kemudian dilihat besaran nilai gain score yang diperoleh yang selanjutnya diinterpretasikan pada keefektifan multimedia pembelajaran Akuntansi berbasis web dalam pencapaian hasil belajar siswa. Hasil perhitungan rerata pre dan post test siswa, diperoleh gain score sebesar 0,43 yang termasuk dalam kategori peningkatan nilai/kriteria gain "sedang". Oleh karena itu, multimedia pembelajaran Akuntansi berbasis web ini dapat meningkatkan hasil belajar siswa terbukti dengan tingginya perolehan nilai gain score hasil belajar.

Selain data hasil belajar siswa, pada evaluasi sumatif juga diperoleh data terkait motivasi belajar siswa. Data yang diperoleh dari angket motivasi belajar yang terdiri atas butir pernyataan sikap siswa tersebut berbentuk data kualitatif, yang kemudian 
diubah menjadi data kuantitatif dengan menggunakan konversi skala angka Likert.

Dari keseluruhan skor yang diperoleh, diketahui bahwa rerata motivasi belajar siswa pada tahap pretest adalah sebesar 3,36 atau termasuk dalam kategori sedang. Sedangkan rerata motivasi belajar pada tahap post test adalah sebesar 3,99 termasuk dalam kategori tinggi. Hasil kedua rerata ini kemudian dibandingkan sehingga diperoleh nilai gain score yang digunakan sebagai acuan penilaian ada tidaknya kenaikan motivasi belajar siswa setelah menggunakan multimedia web.

Dari skor rerata tersebut kemudian diperoleh besaran gain score motivasi belajar siswa, yakni sebesar 0,38 (kategori sedang). Oleh karena itu dapat disimpulkan bahwa terdapat peningkatan motivasi belajar pada siswa setelah menggunakan multimedia pembelajaran Akuntansi berbasis web dalam pembelajaran di kelas.

Berdasarkan hasil evaluasi sumatif, penggunaan multimedia pembelajaran Akuntansi berbasis web sebagai media komplemen kegiatan pembelajaran mendapatkan respon yang positif dari siswa, serta memberikan hasil yang positif bagi peningkatan hasil belajar serta motivasi belajar siswa.

Masukan serta komentar yang diberikan siswa setelah menggunakan multimedia web selama rentang waktu uji coba adalah siswa menginginkan penerapan multimedia web secara menyeluruh dalam proses pembelajaran Akuntansi. Para siswa menyukai pemberian tugas dan latihan oleh guru melalui website studio akuntansi dibandingkan mengerjakannya secara tertulis. Selain itu, waktu akses website yang fleksibel, dapat diakses kapanpun dan dimanapun, membuat siswa menjadi lebih mandiri baik dalam belajar maupun mengerjakan tugas yang diberikan guru.

Sebagai produk hasil pengembangan, multimedia pembelajaran Akuntansi berbasis web memiliki kekurangan dan kelebihan. Kelebihan dari multimedia web ini adalah dapat dipelajari oleh siswa kapan saja dan dimana saja, memiliki tampilan dan penyajian yang atraktif dan menarik serta berbeda dari template website lain karena dikembangkan dengan bahasa pemrograman dinamis (berbasis $P H P$ ). Penyajian yang atraktif tersebut dapat dilihat pada bentuk penyajian menu materi dan bentuk penyajian menu test, yakni pada fitur menu latihan soal dan kuis Akuntansi. Salah satu kelebihan dari latihan dan kuis dalam multimedia web ini adalah disajikan dengan model drag and drop, dimana model penyajian tersebut sangat atraktif dan interaktif untuk menarik perhatian siswa, dimana hal tersebut tidak dapat diberikan oleh media cetak seperti buku.

Selain itu, update data dan penilaian hasil belajar siswa dapat dilakukan secara lebih mudah karena dilakukan secara transparan melalui personal database siswa. Komunikasi guru dan siswa pun tidak lagi hanya terbatas pada jam sekolah, serta dapat meningkatkan kemandirian dan kedisiplinan siswa dalam belajar dan mengerjakan tugas karena sifat dari media komputer yang lebih personal atau individu.

Kelemahan dari produk ini adalah belum dilengkapi dengan adanya fitur tambahan yang mendukung materi Akuntansi, seperti video pembelajaran Akuntansi. Selain itu, web ini belum dilengkapi dengan fasilitas pendukung lain seperti audio atau playlist music guna mendukung siswa dengan gaya belajar auditori, serta belum adanya fasilitas chatting personal dalam berkomunikasi dengan guru ataupun dengan user lain. Kekurangan lain dari produk web ini adalah hanya bisa digunakan secara online oleh sekolah atau user yang memiliki jaringan internet memadai. Ketersediaan bandwidth/jaringan internet yang ada juga mempengaruhi kelancaran akses pada website sehingga dapat menghambat pelaksanaan proses pembelajaran online. Selain itu, cakupan materi dalam multimedia web hanya sebatas pada 4 materi pokok KD Struktur Dasar Akuntansi, belum mencakup keseluruhan materi Akuntansi untuk Kelas XI IPS. Hal tersebut menjadi masukan bagi pengembang dalam melakukan pengembangan produk pada tahapan lebih lanjut. 


\section{Simpulan}

Berdasarkan hasil pengembangan dan analisa data produk multimedia pembelajaran Akuntansi berbasis web, maka dapat disimpulkan: Pertama, Multimedia pembelajaran Akuntansi berbasis web pada mata pelajaran Akuntansi kelas XI IPS dikembangkan menggunakan bahasa pemrograman dinamis (berbasis $P H P$ ) melalui prosedur pengembangan produk yang meliputi: (1) Tahap perencanaan, dilakukan dengan mendefinisikan ruang lingkup kajian materi yang meliputi penentuan standar kompetensi (SK) memahami penyusunan siklus Akuntansi perusahaan jasa dengan kompetensi dasar (KD) struktur dasar Akuntansi, mengidentifikasi karakteristik siswa subjek uji coba yakni siswa kelas XI IPS 2 SMA Negeri Yogyakarta, menentukan batasan/ketentuan multimedia web, menentukan standar desain multimedia, menentukan dan mengumpulkan sumber referensi materi Akuntansi, dan melakukan brainstorming dengan guru mata pelajaran Akuntansi; (2) Tahap desain dilakukan dengan melakukan analisis konsep materi Akuntansi dan jenis tugas seperti pembuatan RPP dan penentuan jenis tes hasil belajar, serta membuat struktur desain multimedia pembelajaran berbasis web berupa pembuatan flowchart dan storyboard multimedia web; (3) Tahap pengembangan meliputi menyiapkan teks materi Akuntansi yang di upload, membangun multimedia pembelajaran dengan basis pemrograman PHP, menggabungkan tiap-tiap komponen multimedia, menyiapkan materi pendukung, evaluasi formatif dan evaluasi sumatif.

Kedua, kualitas multimedia pembelajaran Akuntansi berdasarkan hasil validasi ahli dan ahli media dinyatakan layak digunakan dalam uji coba tahap selanjutnya. Sedangkan penilaian kesan siswa terhadap multimedia web memperoleh skor rerata 4,23 dengan kategori skor sangat baik. Berdasarkan penilaian tersebut maka multimedia web Akuntansi yang dikembangkan layak digunakan pada evaluasi sumatif siswa kelas XI IPS 2.
Ketiga, hasil evaluasi sumatif penggunaan multimedia web Akuntansi di kelas XI IPS 2 menunjukkan bahwa: (1) terdapat peningkatan pencapaian hasil belajar siswa setelah menggunakan multimedia web Akuntansi dalam kegiatan pembelajaran. Nilai rata-rata pretest adalah sebesar 7,08, sedangkan nilai rata-rata post test meningkat menjadi 8,34. Terdapat peningkatan hasil belajar belajar siswa dengan persentase sebesar 17,80\%. Peningkatan skor (gain score) nilai rata-rata seluruh siswa dari hasil pretest dan post test adalah sebesar 0,43 (kategori sedang); (2) Terdapat peningkatan motivasi belajar siswa setelah menggunakan multimedia web Akuntansi dalam kegiatan pembelajaran. Skor rata-rata motivasi belajar pada tahap pretest adalah sebesar 3,36 (kategori sedang), sedangkan nilai ratarata post test meningkat menjadi 3,99 (kategori tinggi). Peningkatan skor (gain score) rata-rata motivasi belajar seluruh siswa dari hasil pretest dan post test adalah sebesar 0,38 (kategori sedang).

Terjadinya peningkatan skor hasil belajar dan motivasi belajar siswa pada hasil evaluasi sumatif, yang diklasifikasikan pada tahap "Sedang" berdasarkan kategori nilai gain score Hake, diinterpretasikan sebagai implikasi atas terbatasnya waktu penelitian sehingga efektivitas penggunaan produk multimedia pembelajaran Akuntansi berbasis web terhadap kegiatan pembelajaran di kelas belum optimal.

Berdasarkan kesimpulan dalam penelitian ini, maka dapat peneliti sarankan: Pertama, multimedia pembelajaran Akuntansi berbasis web ini dikembangkan sesuai dengan silabus mata pelajaran Akuntansi serta telah melalui proses validasi ahli materi, ahli media dan diujicobakan pada siswa. Oleh karenanya, guru Akuntansi diharapkan dapat menggunakan produk multimedia web Akuntansi dalam kegiatan pembelajaran di kelas untuk terciptanya proses pembelajaran yang inovatif dan interaktif.

Kedua, agar memperoleh hasil yang efektif, maka pemanfaatan produk multimedia pembelajaran Akuntansi berbasis 
web ini harus dilakukan dengan cara yang tepat., yakni: (1) bagi guru mata pelajaran Akuntansi, disarankan untuk memberikan penjelasan terlebih dahulu kepada siswa mengenai produk multimedia web serta petunjuk penggunaannya, (2) bagi siswa, disarankan untuk mengikuti seluruh petunjuk penggunaan web Akuntansi sebelum melakukan kegiatan pembelajaran dengan media tersebut.

\section{Daftar Pustaka}

Alessi, S. M., \& Trollip, S. P. (2001). Multimedia for learning: methods and development (3rd ed.). Boston: Allyn and Bacon.

Arsyad, A. (2009). Media pembelajaran. Jakarta: PT Raja Grafindo Persada.

Boulton, H. (2008). Managing e-learning: What are the real implications for school? Electronic Journal E-Learning, $6(1), 11-18$. Retrieved from www.ejel.org/volume-6/v6i]/Boulton.pdf

Departemen Pendidikan Nasional. (2009). Panduan pengembangan silabus SMA mata pelajaran IPS terpadu. Jakarta: Departemen Pendidikan Nasional.

Ebel, R. L., \& Frisbie, D. A. (1991). Essentials of educational measurement. New Jersey: Prentice Hall.

Hake, R. R. (1998). Interactive-engagement versus traditional methods: A sixthousand-student survey of mechanics test data for introductory physics courses. American Journal of Physics, 66(1), 64-74.

https:// doi.org/10.1119/1.18809

Januarisman, E., \& Ghufron, A. (2016). Pengembangan media pembelajaran berbasis web mata pelajaran ilmu pengetahuan alam untuk siswa kelas VII. Jurnal Inovasi Teknologi Pendidikan, 3(2), 166.

https:// doi.org/10.21831/jitp.v3i2.80 19

Mu'arif, H. A., \& Surjono, H. D. (2016). Pengembangan e-learning berbasis pendekatan ilmiah pada mata pelajaran IPA di SMP Negeri 5 Yogyakarta. Jurnal Inovasi Teknologi Pendidikan, 3(2), 195. https:// doi.org/10.21831/jitp.v3i2.11 143

Patmanthara, S. (2007). Pembelajaran melalui internet di perguruan tinggi. Jurnal Teknodik, 20(XI), 57-70.

Prasojo, L. D. (2011). Teknologi informasi pendidikan. Yogyakarta: Gaya Media.

Purmadi, A., \& Surjono, H. D. (2016). Pengembangan bahan ajar berbasis web berdasarkan gaya belajar siswa untuk mata pelajaran Fisika. Jurnal Inovasi Teknologi Pendidikan, 3(2), 151. https:// doi.org/10.21831/jitp.v3i2.82 85

Sardiman. (2003). Interaksi dan motivasi belajar mengajar. Jakarta: Raja Grafindo Persada.

Sukardjo. (2005). Evaluasi pembelajaran. Diktat mata kuliah program studi teknologi pembelajaran Universitas Negeri Yogyakarta. Yogyakarta: tidak diterbitkan.

Warsita, B. (2006). Kecenderungan global dan regional dalam pemanfaatan teknologi informasi dan komunikasi untuk pendidikan. Jurnal Teknodik, 10(19), 069. https:// doi.org/10.32550/teknodik.v1 0 i19.394 